\title{
British reluctance to pay tries patience of its ESA partners
}

\section{London}

AT next week's autumn council meeting of the European Space Agency (ESA), each member state will approve the 5 per cent annual increase in the science budget. Except perhaps Britain. Most of the ESA members are eager to get on with Horizon 2000 , the centrepiece of the science programme, and are frustrated by Britain's caution. So will Britain give way? That was the question in the minds of space

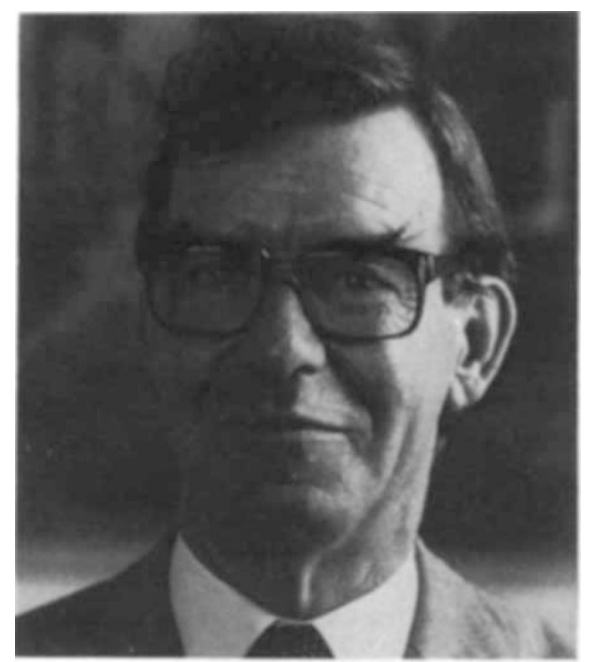

Professor Reimar Lüst says UK must pay.

scientists at a seminar called "Space and the United Kingdom - Quo Vadimus" held at the Royal Society last week.

Professor Reimar Lüst, director general of ESA, strongly hinted to the British government that another veto on the annual increase would be unacceptable. The science programme is the "backbone" of ESA, he said. "It is essential that every member state is willing to pay its share." Each member's contribution is the annual "fee" to belong to the club, and if the majority agrees on the size of the fee, then others must fall into line.

Professor Roger Bennett, director of the science programme, said after the seminar that he expected Britain to approve the increase. "They vetoed it last time and we are not expecting them to do it again."

\section{Job for Trivelpiece}

\section{Washington}

Alvin Trivelpiece is to leave his post as executive officer of the American Association for the Advancement of Science (AAAS) to become director of the Department of Energy's (DoE) Oak Ridge National Labotatory. Trivelpiece joined AAAS last year after six years as director of the DoE's Office of Energy Research.

Joseph Palca
The head of the British National Space Centre (BNSC), Arthur Pryor, declined to reveal the government's plans. But the space community is not optimistic. "It could come to a rather nasty crunch", said Professor Kenneth Pounds, of the University of Leicester. The other members are determined to go ahead, and they feel so strongly about it now that if Britain vetoes the increase, it might be "pushed out" of ESA. It, could be relegated to associate membership; a remarkable position for one of the founder members of the agency to be in, he said.

British space scientists are embarassed by the government's attitude towards ESA. And at the seminar, Lord Shackleton openly apologized to Lüst for the "shocking" behaviour of Britain's ministers. He thanked ESA for its "tolerance and kindness" when Britain's ministers had been "positively offensive". Their haggling over costs may have "irreversibly damaged" Horizon 2000. Britain's partners in ESA "might prefer we lived on a different continent", said Professor David Southwood of Imperial College, London.

If Britain did veto the increase, Horizon 2000 would be stretched so far into the future that it would lose its credibility, said Bonnet, and Europe would fall behind its competitors. The whole thing would have to be "scrapped and redesigned" said Pounds, and it was not "luxurious" to start with. Even the first cornerstone, the solar-terrestrial science project, which was finalized in August (see Nature 334, 643; 1988), would have to be reconsidered.

The planned 5 per cent increase on the present budget of 200 million ECU, about $£ 140$ million, would increase Britain's contribution by $£ 1$ million; a "trivial" sum, says Pounds, to add to the national budget of $£ 130$ million. And the losses to the country in terms of industrial contracts and scientific opportunities would be far greater.

Britain has argued two ways of reducing its contribution. Bonnet said both were unacceptable. One was to make the science programme optional. The other was to reduce the contributions of all members as three countries, Austria, Finland and Norway, have recently joined. But funds from the new members barely cover the increase in costs caused by mission delays, said Bonnet.

If Britain relinquishes its status as full member, that could signal the beginning of the decline of its space science, said Pounds. Young researchers will go abroad and the space community will age, as it has done in the United States. And Pryor's attitude is not encouraging. Data- processing "may be the centrepiece of what we can achieve", he said. But without a close relationship between research and theory the subject is dead, said Pounds.

Speaking at the seminar, Pryor said that the BNSC would not lead the country's efforts in space and there would be no national plan, but possibly a "chart", though what that will be remains somewhat vague. When asked how the space community could put its case better to the government, he said that ministers were not motivated solely by the "blindingly obvious". But he assured researchers that there was no "great conspiracy" against them.

Funding problems are holding back another of ESA's projects. ERS-2, the European remote sensing satellite due to take over the role of ERS-1 in 1993, is in jeopardy because Britain and France have not agreed to fund it. Of the 13 participants in ERS-1, they are the only two which have not agreed to support its replacement, but together they are due to contribute 50 per cent of the budget. Their contributions are relatively high because of the significant industrial returns they received from ERS-1. Last week, Pryor questioned this system, saying that "fin-

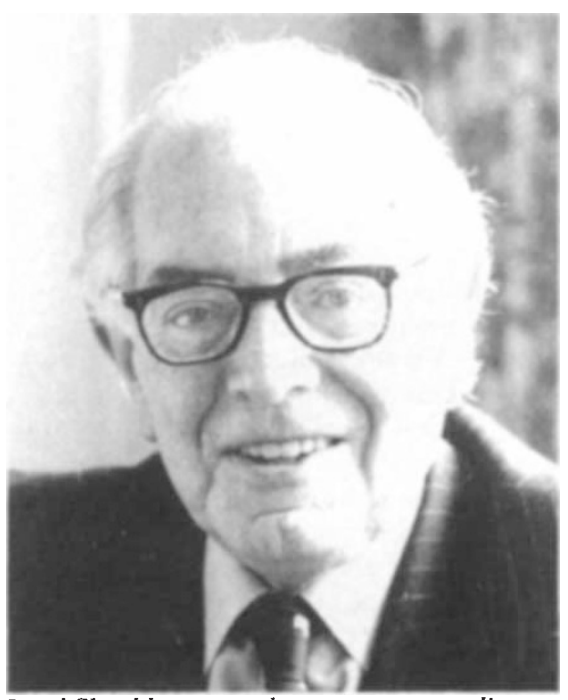

Lord Shackleton attacks government policy.

ancial capability does not always match technological capability".

The mission manager for the ERS satellites, Guy Dochossois, said the situation was now very difficult. The other members are keen to go ahead, but without Britain and France ERS-2 will have to be abandoned because their expertise would be difficult to find elsewhere. If it is abandoned there will be a data gap of two to three years between the end of the lifetime of ERS-1 and the availability of data from the polar platform, ESA's main contribution to the Columbus space station programme. Lüst said that if Britain had to make a choice, it should fund ERS2 and not the polar platform, which is over-subscribed.

Christine McGourty 